\title{
Proceedings of the Twenty-ninth Annual General Meeting
}

The Annual Meeting of the British Paediatric Association was held at the Old England Hotel, Windermere, from April 23 to 26, 1958.

Business Proceedings. Dr. K. H. Tallerman, M.C., took the Chair as President, and the following members were present:

F. M. B. Allen, E. C. Allibone, I. M. Anderson, J. Apley, Cécile Asher, R. Astley, H. S. Baar, T. E. D. Beavan, M. Bodian, R. E. Bonham Carter, J. V. Braithwaite, P. T. Bray, E. G. Brewis, F. S. W. Brimblecombe, R. W. Brookfield, W. A. B. Campbell, W. H. Cant, N. B. Capon, I. A. B. Cathie, N. S. Clark, T. Colver, W. R. F. Collis, Beryl Corner, S. D. M. Court, John Craig, J. O. Craig, W. S. Craig, Mildred Creak, J. Crooks, W. E. Crosbie, K. W. Cross, Mary Crosse, G. Davison, E. F. Dott, A. C. Doyne Bell, S. Doxiadis, J. L. Emery, P. R. Evans, H. L. Ellis, J. W. Farquhar, J. O. Forfar, Isabella Forshall, A. White Franklin, D. Gairdner, W. Gaisford, W. H. Galloway, R. R. Gordon, S. Graham, C. F. Harris, E. W. Hart, J. Hart-Mercer, C. C. Harvey, J. D. Hay, J. L. Henderson, W. Henderson, A. Holzel, F. P. Hudson, J. H. Hutchison, R. S. Illingworth. J. Jacobs, N. M. Jacoby, Ursula James, H. Jolly, H. Everley Jones, F. F. Kane, J. J. Kempton, G. M. Komrower, R. C. Lightwood, J. Lorber, P. MacArthur, R. A. McCance, D. MacCarthy, Agnes MacGregor, M. MacGregor, R. Mac Keith, T. P. Mann, R. Mayon-White, R. A. Miller, F. J. W. Miller, A. V. Neale, G. H. Newns, D. N. Nicholson, A. P. Norman, J. N. O'Reilly, C. G. Parsons, W. W. Payne, C. Pinckney, P. E. Polani, C. T. Potter, K. B. Rogers, A. Russell, L. Scott, R. A. Shanks, W. Sheldon, Ursula Shelley, Victoria Smallpeice, W. C. Smallwood, J. M. Smellie, J. Forest Smith, T. Stapleton, J. Thomson, M. L. Thomson, J. P. M. Tizard, R. McL. Todd, W. Walker, A. G. Watkins, Cicely Williams, Mary Wilmers, B. D. R. Wilson, D. W. Winnicott, Winifred Young, S. Yudkin.

Professor Bo Vahlquist (Windermere Lecturer) and Mr. G. J. Piller were the guests of the Association.

The following were present as guests of members of the Association:

E. Aberdeen, Charlotte Anderson, J. Baden-Daintree, R. Berg, M. F. G. Buchanan, Bera Buhrmann, Joyce Burke, E. D. Burnard, Joan M. Cashman, C. L. Chen, P. Clay, B. L. Coles, Christine Cooper, J. G. A. Davel, W. Dickson, J. H. Diggle, E. E. Doyle, D. Garrow, S. Griffin, A. D. M. Jackson, Margaret Jones, A. C. Kirby, K. M. Laurence, R. Llewelyn Davies, D. Macaulay, A. E. McCandlass, W. J. Matheson, Florence Mayer, J. Olsen, A. W. M. Page, F. Puga, A. Rigg, H. Rischbieth, S. Sjölin,
Jean Smellie, F. H. Stone, G. Weston, D. Whitehouse, T. Wright.

The Annual General Meeting was held on April 24, 1958.

The Minutes of the last meeting, which had been published in the Archives of Disease in Childhood, were received and approved.

ELECTION OF OfFICERS. The following were elected:

President: Dr. J. Forest Smith.

President-Elect: Dr. R. C. Lightwood.

Treasurer: Professor A. G. Watkins.

SECRETARY: Dr. P. R. Evans.

EXeCutive CommitTeE, 1958-61 :

Dr. J. Apley, Dr. D. V. Hubble, Dr. P. Mac-

Arthur, Dr. L. G. Scott, Dr. E. W. Hart (1958-59).

Election of Members. The following were elected:

\section{HONORARY MEMBERS}

Dr. K. H. Tallerman, Dr. H. S. Baar, Dr

Frances Braid, Professor C. Dent, Dr. A. Go Ogilvie, Dr. T. Pearse Williams.

\section{CORRESPONDING MEMBERS}

Professor S. T. Achar (Madras), Dr. R. C. Eley (Boston), Dr. A. Hartman (St. Louis), Professor D. B. Jelliffe (New Orleans), Professor E. Kerpel-Fronius (Pecs, Hungary), Dr. A. B. Sabin (Cincinnati).

\section{ORdinARY MEMBERS}

A. G. V. Aldridge, G. C. Arneil, A. D. Barlow, R. G. G. Barry, T. Bowlby, T. A. Brand, J. Coates, Christine E. Cooper, E. C. R. Couper, M. E. Disney, H. G. Farquhar, H. V. L. Finlay, B. Gans, I. H. Gosset, Gwyn R. Griffith, Sylvia K. Guthrie, T. B. Heycock, C. J. Hodson, ิ R. Jenkins, C. W. Kesson, A. M. MacDonald, R. G. Mitchell, C. Newman, A. P. M. Page, N L. J. Prosser, P. P. Rickham, T. S. Rodgers, J. M. Stansfeld, W. P. Sweetman, P. N. Swift, D. H. Wallace, H. R. E. Wallis, C. B. M. Warren, I. G. Wickes, D. A. J. Williamson, B. S. B. Wood, Barbara Woodhead.

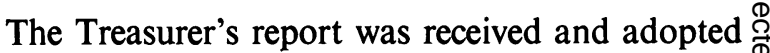
and the auditors were re-appointed for a further $\stackrel{\circ}{0}$ 
year. The thanks of the Association were expressed to Dr. R. Lightwood at the expiry of his 11 years' work as Honorary Treasurer.

The report of the Executive Committee was received and approved and is printed below. It was agreed that next year's report should include the names of members of committees. Following a suggestion made by Dr. Beryl Corner it was agreed that the Executive Committee should arrange for more prolonged discussion on paediatric policy, either at the Annual General Meeting or at a special meeting held at another time during the year:

A proposal to alter Rule 15 to read:

'The subscription payable by ordinary members shall be fixed from time to time by the Executive Committee and reported to the members of the Association',

was referred back to the Executive Committee for further consideration.

There was considerable discussion of an offer by the Journals Committee of the British Medical Association to allow members of the Association to receive the Archives of Disease in Childhood at a reduced rate of subscription provided that virtually all members subscribed. On a show of hands the following resolution was passed by 42 votes to 37 : 'That the Executive Committee should consider consolidating the subscription to the Association and to the Archives of Disease in Childhood'.

\section{Report of the Executive Committee 1957-58}

1. We note with sorrow the death of four original members, Dr. A. G. Maitland Jones, Dr. Wilkie Scott, Dr. William Brown and Dr. H. C. Cameron.

2. We congratulate Professor A. A. Moncrieff on his election to fellowship of the Royal College of Obstetricians and Gynaecologists, and Dr. C. F. Harris on his nomination as Vice-Chancellor of the University of London.

3. RePORTS AND Committees. The report on hospital accommodation for children was published in the Lancet in July, 1957. The report of the Child Psychology Committee on child guidance has been submitted to the Ministry of Health. Written evidence has been submitted to the Platt Committee on the welfare of children in hospital. At the request of the Ministry of Agriculture, Fisheries and Food draft regulations on soft drinks have been studied in relation to child health and comments have been submitted. A Committee has been set up to consider paediatric care in infectious diseases hospitals and sanatoria, and another to discuss the medical care of adolescents. The Joint Committee on Prematurity has been replaced by a Standing Joint Committee of the British Paediatric Association and Royal College of Gynaecology, which will consider matters of common interest.

4. Meetings. It will be impossible to hold future meetings in Windermere and the Executive recommends that in 1959 the Annual General Meeting should be held at the Royal Hotel, Scarborough. The Canadian Paediatric Society has suggested having a joint meeting with us in Britain in 1961, and it is proposed that it shall replace our usual annual meeting in that year.

5. Diploma of Child Health. Regulations for the D.C.H. demand from clinical assistants four attendances a week. In order to encourage general practitioners to take the examination the Conjoint Board has been asked to approve less frequent attendance over a longer period and has agreed to do so.

6. Children in Adult Wards. One of the main topics for discussion during the past two years has been the question of how many children who could be nursed in children's wards are admitted to adult wards. Further information is being collected: there appears to be much regional variation.

7. Windermere Lecture. Professor Bo Vahlquist (Uppsala) delivered the Windermere Lecture entitled 'Breast milk and cow's milk in infant feeding: a clinical, serological and biochemical study in 400 children'.

\section{Scientific Sessions}

UrSula JAMES (London). 'The Diagnosis of Urinary Infection in the Newborn.' Observations on the incidence and diagnosis of urinary infections in the newborn have been made over a period of one year in a maternity unit of 65 beds. The clinical picture and urinary investigations have been analysed, and the results compared with similar investigations in 100 normal infants. The value of actual white cell counts in the urine has been investigated, and a range of cell counts in normal infants has been compared with those found in patients with urinary infections. Suggestions are offered for making early and more certain diagnosis of infections of the urinary tract in the newborn.

W. S. Craig and M. F. Buchanan (Leeds). 'Hypocalcaemic Tetany on the Second Day of Life.' To be published in full.

F. H. Stone (Glasgow). 'Infantile Autism.' The clinical features of infantile autism (Kanner's syndrome), based on the intensive study of several cases, were described and illustrated by means of a cine-film. Aetiological factors were considered and an experimental therapeutic approach described. Suggestions were made as to future lines of research.

G. M. Komrower (Manchester). 'Sequelae of Infantile Renal Acidosis.' To be published in full. 
W. GAISFORD (Manchester). 'Poliomyelitis Vaccination of Newborn Infants.' Groups of newborn infants were given poliomyelitis vaccine and their titres examined to see if maternally transmitted antibodies inhibited the natural development of antibodies after vaccination and whether triple negative infants would produce reasonable titres. The effect of a booster dose seven to eight months later was also investigated.

D. GAIRDNER (Cambridge). 'The Fluid Shift from the Vascular Compartment Immediately after Birth.' To be published in full.

K. M. LAurence (London). 'The Natural History of Hydrocephalus.' It is generally believed that, untreated, few children with hydrocephalus survive and that those who do survive are doomed to permanent institutional care. Nearly 200 cases of untreated hydrocephalus, seen by Mr. Wylie McKissock (who rarely operates upon this condition) since 1939, have been followed up. Fortysix per cent of the series have survived with the hydrocephalus spontaneously arrested. These have been re-examined and intelligence tested. Many of those who showed evidence of spasticity and incoordination in infancy have now no 'motor trouble', and on intelligence testing $44 \%$ fall within the 'average' group (I.Q. of 85 and above). A further $20 \%$ are educable with an I.Q. of above 50 , leaving only $25 \%$ requiring complete institutional care. Thirty-five per cent of the survivors are growing up as completely normal individuals, both physically and mentally. Children with acquired hydrocephalus, generally due to a basal cistern block, bore the most hopeful prognosis.

In the light of this a more hopeful approach to this condition is called for, in spite of the fact that the disease often causes some brain damage, and that mental development in many cases is temporarily delayed in the early years.

I. A. B. Cathie (London). ' 'On Editing the Archives.' The general functions of an editor and his responsibility to contributors and readers were briefly considered and the experience of nine years editing the Archives of Disease in Childhood was analysed. The types of articles submitted for publication were considered, the reasons for rejections given and the principles involved in the editing of accepted papers were discussed. Common discordances in the construction of papers and the presentation of results were outlined, as were some of the commoner grammatical extravagances. Finally, an attempt was made to indicate the type of paper most likely to give the maximum information in the minimum space and require the least amount of alteration and therefore be most acceptable.

Christine E. CoOper and S. Griffin (Newcastle). 'Oesophageal Stricture Secondary to Hiatus Hernia.' An account was given of 18 cases seen since 1952 during a study of hiatus hernia in 356 infants. The age range was 2 months to 12 years when first seen. Stricture was already present at the first visit in 15. Many had been previously treated as behaviour problems. Details of history and clinical diagnosis were presented. The importance of an experienced radiologist and careful technique during barium studies was emphasized. A preliminary account of conservative management in $\mathbf{1 5}$ and radical surgery in three, description of complications and emphasis on need for long-term study were given.

A. D. M. JACKSON and L. Fisch (London). 'Deafness following Maternal Rubella: Results of a Prospective Survey.' Detailed clinical examinations and hearing tests (including audiograms) were carried out on a series of 57 children, whose mothers were known to have had rubella during the first 18 weeks of pregnancy. Fiftyseven controls were also examined.

The children were taken from the records of the national prospective enquiry into the effects of virus infections in pregnancy organized by the Society of Medical Officers of Health and the Ministry of Health.

A preliminary report of the findings of this investigation was presented. The results will be published in full elsewhere.

JeAn Smellie (London). 'The Effect on the Infant of Large Therapeutic Doses of Vitamin D given to the Mother throughout Pregnancy.' The clinical and biochemical follow-up were described on two infants now aged 6 months and 2 years, born to a mother suffering from severe Type I renal tubular osteomalacia. She had been successfully treated with A.T. 10 for six months before the first pregnancy and received pure dihydrotachysterol throughout both pregnancies $(1 \mathrm{mg}$. o.d. by mouth).

Both infants showed biochemical signs of mild vitamin D intoxication, namely a low plasma alkaline phosphatase and a slightly raised serum calcium followed by a rise of blood urea.

Lactation was suppressed in each case. In the first, the infant was fed on National Dried Milk and between 2 and 3 months became hypotonic with increased reflexes. These signs disappeared when the National Dried Milk was replaced by liquid cow's milk. The second child, fed on liquid cow's milk from birth, showed no hypotonia.

The implications of these findings were discussed, particularly in relation to the aetiology of idiopathic hypercalcaemia of infancy; for instance, that an infant may be 'sensitized' in utero to vitamin $D$ by an excessive maternal intake of vitamin $D$ during pregnancy in health foods and vitamin capsules.

Malcolm MacGregor (Warwick). 'Osteomyelitis Variolosa.' There is only one account in British literature, in 1887, of this interesting bone complication of smallpox, of which I had the opportunity to study 20 cases in Nigeria last year.

This short paper illustrates the condition, which is radiologically very striking, and draws some parallels with other virus affections of bone, more likely to be in the minds of members of the B.P.A. 